\title{
Research and Practice of Alumni Cultural Education
}

\author{
Yeqing Wang, Xiao Tong, Biao Qin
}

Xi'an Shiyou University, Xi’an, Shaanxi, China, 710000

\author{
Keywords: Research, Practice, Alumni Cultural Education
}

\begin{abstract}
Alumni culture refers to the unique culture created by alumni in the long run of their alma mater. It is an emotional connection between schools, alumni and society, and is a spiritual link that brings together alumni. The alumni culture, based on the relationship among the students has richness, cohesion, vividness, identity and inheritance, so it can be used as valuable college ideological and political education resources. Cultural education has its deep basis and connotation. As a kind of culture, alumni culture has its unique significance and potential value. It also plays an irreplaceable role in the ideological and political education of college students.
\end{abstract}

\section{Introduction}

Culture is a universally recognized ideology that can be inherited from one another and is an indispensable spiritual force in the survival and development of a nation or nation. Culture is the historical precipitation that people create for a long time, and culture affects people's way of life and behavior. China has always attached great importance to the building of culture. In November 2013, the Third Plenary Session of the 18th CPC Central Committee held in Beijing proposed that "building a strong socialist culture and enhancing the country's cultural soft power". Culture has a great binding force and cultural education is to "text" to "transform" people. As the cradle of cultivating socialist countries and realizing the great rejuvenation of dreams in China, colleges and universities should attach importance to the importance of culture in educating people as an important front for cultural creation, transmission and inheritance. Culture has its profound connotation. It plays a guiding role in educating and nurturing talents. It plays an irreplaceable role in educating and nurturing talents [1]. It can serve as an effective resource for ideological and political education, builds a new education platform, and enhances students' ideological and moral accomplishments and scientific and cultural qualities.

Alumni culture provides a new direction for the cultural construction of colleges and universities and can be exploited and utilized as a new carrier of ideological and political education in colleges and universities. With the vigorous development of education in our country, the competition among colleges and universities is mainly reflected in the quality of personnel training. In addition to mastering solid professional knowledge, college students should have noble moral sentiments, sound thinking personality and correct values, which are all the goals and contents of college students' ideological and political education. Many colleges and universities have recognized the importance of "cultural education" in their development. With the continuous expansion of the university scale in our country and the continuous increase of the number of graduating alumni, a new culture - alumni culture is gradually being well known and utilized by all colleges and universities. Alumni culture is the most long-lasting fundamental factor for the common development of schools and alumni. It is also a characteristic element of inheriting school spirit, expanding school influence and enhancing the vitality of the school. With its strong attraction, affinity and cohesion, alumni culture is huge magnetic effect, the students, old and new alumni and other relevant parties together to form a common vision and goals based on the overall advantages and superposition effect [2].

Alumni culture plays an irreplaceable role in college students' ideological and political education with its unique charm and potential value. The relationship between college ideological and political education and alumni culture is interrelated and mutual infiltration. The ideological and political education in colleges and universities has guaranteed the alumni culture development and 
influenced and created a new alumni culture. Alumni culture has expanded the content of ideological and political education, enriched the connotation of cultural education in colleges and universities, and provided a new platform for ideological and political education in colleges and universities. Throughout many colleges and universities at home and abroad, there are many successful, can learn from, with a distinctive outstanding alumni culture. On the path of personnel training, alumni culture has become an important "booster" for the development of these universities, bringing teachers and students together in the school closely. Awareness of these universities in alumni culture construction strategies and practices, for our alumni culture education practice mirror. In view of the alumni culture plays a very important role in the personal development of college and alumni, this essay intends to shed light on the value and function of alumni culture in the ideological and political education of college students, the status quo and cause analysis of the alumni culture ideological and political education, as well as give full play to Alumni culture in the ideological and political education of college students in the important role of specific measures and other aspects to elaborate the views of this article.

\section{Related Research on the Alumni Culture}

Alumni culture is a kind of community culture based on the relationship between learning and learning, which refers to the emotional maintenance, value recognition, communication and exchange of services between alma mater and alumnus, alumni and alumni formed by colleges and universities in the long run of running a school such as the spiritual phenomenon of the summary. Alumni culture is not alumni culture, because in addition to alumni, school staff, school students and graduates are the formation of the main alumni culture; alumni culture is not equivalent to the university culture, because as alumni graduate to society, alumni culture The dissemination of connotation has not only been confined to the university campus, but extended to the outside world, into the community.

Alumni culture is the result of long-term interactions between alma maters and their groups and their members (alumni) in a common learning life. It is a result of interactions between alumni and various activities through mutual contact and co-cultivation. College cultural development requirements as the background to alma mater as a base for cultivating alumni culture, school eduction of traditional culture and rigorous alumni work as a driving force to the same growth environment and the campus landscape as a common memory, similar to learning experience and knowledge structure as the cultural basis, the development process of his alma mater's struggling history and the alumni's learning spirit, the humanistic concern of his alma mater and the alumni love school complex as the emotional and material integrated cultural body [3]. Alumni culture has extremely rich spiritual values and cultural connotations, and plays an irreplaceable role in the construction and development of colleges and universities, the growth of alumni, and the ideological and political education of college students.

Alumni culture is morphologically an emotional culture, which is a kind of gratitude culture. As a sentiment culture, alumni culture is sincere and natural, with distinctive characteristics of being easy to trigger and sustaining emotionally. As a grateful culture, alumni culture incorporates a dignified morality. It is even more a traditional virtue of the Chinese nation to know and give thanks. The formation of alumni culture, there are two main factors: First, alma mater, one is alumni. Schools and alumni make a healthy and active alumni culture when they value their relationships and are willing to work hard. There is an eternal historical relationship between the alumni and the school and the long-standing relationship between the two. They are associated with the rise and fall of the school through their honor and disgrace, complement each other and seek common development. Alumni reflect the level of running a school. They are a mirror to test school work. Their popularity in society is a manifestation of the quality of school running. Whether they succeed in society or not is a school education success or failure Sign. At the same time, alumni are also strong sources of resources to support the development of schools. Alumni are talents nurtured by schools. They are the brand and image of schools. Alumni activities expand the influence space and development of schools at all levels of society in all walks of life space. Their achievements in 
business, feedback to the school for information, advice and investment in running schools, endowment funds, cooperation in running schools and other aspects of support, so that the school added value of intangible assets, and promote the development of the school.

\section{The Content of Cultural Education}

Culture plays an irreplaceable role in promoting the overall strength of the country and its international competitiveness and in promoting the progress of the Chinese nation. Cultural education is an important part of ideological and political education. Cultural transmission and innovation, value guidance and people-oriented are the values of effectiveness of ideological and political education.

An Important Feature of Chinese Traditional Culture Thought is Adhering to Culture and Education. As the most important place for teaching and educating people in our country, after long-term historical development and practice, colleges and universities create, spread and develop their own unique culture, have profound cultural connotations and precipitate unique university culture. With the continuous growth of the number of colleges and universities in our country and the continuous development of higher education, colleges and universities attach more and more importance to the cultural construction of our university. As the cradle of cultivating national talents, colleges and universities in our country should strengthen the cultivation of college students' cultural education and enhance the cultural force of ideological and political education. Integrating the core values of socialism into the cultural construction of university alumni, the teachers and students in colleges and universities can learn and live in a good atmosphere and can all be influenced by the positive culture. The enlightenment, influence and guidance of undergraduates who are in the critical period of the formation of the ideological and moral character can promote the self-improvement and all-round development of the ideological and moral qualities of the undergraduates, so as to improve the personnel training mode in colleges and universities. Cultural education is an important part of ideological and political education. The ideological and political education activities of Chinese college students have cultural attributes. They are the inheritance and development of culture on the basis of accumulating and innovating the profound cultural background, and on the basis of which the cultivation of talents and education Innovation.

\section{The Role of Alumni Cultural Education Research and Practice}

The ideological and political education in colleges and universities in our country is a huge systematic project. The ideological and political education in colleges and universities is facing severe challenges and opportunities need to be seized, looking for new ways and means. Traditional ideological and political education because of its many shortcomings, in some areas has gradually shown signs of failure to meet the requirements of the development of the times, so the urgent need for reform and innovation.

As a kind of college culture, alumni culture can enhance college students' moral cultivation and improve college students' mental outlook by virtue of their cultural background and cultural atmosphere. From this point, alumni culture has the same guiding value as college students' ideological and political education so as to achieve the same effect.

The alumni relationship based on the relationship of learning contains the value of emotional education. Alumni culture is one of the important resources in college education and teaching. As a background culture, alumni culture enables people living in it to receive education unknowingly and form correct habits of thinking and codes of conduct. This is a very strong educational function embodied in the alumni culture. Emotional education in culture can really bring forth the educational effect that cannot be achieved by the positive education. It is a subtle influence and influence on the educating people. It is totally different from the instructors' far higher than the traditional classroom education.

Successful alumni embody the value of motivational demonstration. The successful experience of outstanding alumni set a good example for the students and played an exemplary role in 
motivating the students to challenge themselves and realize themselves. For example, Guan Jing gave the following definition in his essay, "The Formative Role and Release of Model": "The model education method is to use a representative person or thing to demonstrate and inspire and help others Improve their own ideological and political consciousness of an educational method. "The role of example education to better resonate the positive effect of education is an intuitive way of thinking and political education and a vivid way, the example of college students can be the correct guide to promote the noble the formation of morality [4].

The allegiance to alma mater contains the value of unity and cohesion. Alumni have a strong sense of dependency and belonging to their alma maters, while their alma maters are both a guide and a centripetal force for alumni. Alumni also share a classmate's love for their common learning experiences and knowledge background. Alma mater has a natural connection with alumni, and together creates their own alumni culture, which contains a strong natural cohesion and emotional cohesion. Natural cohesion is manifested in the following: When alumni leave their alma mater to integrate into society, fierce social competition will make them feel frustrated and spontaneously find their care and support from their alma mater, thus psychologically having a stronger sense of belonging. Emotional cohesion is manifested as a love of alumni school, alumni respect for teachers and classmates love between classmates.

Inheritance and development of alumni culture contains the value of radiation. Alumni culture also has a very strong value function of social radiation. When the first session of the students to enter his alma mater, a group of graduates out of school become the pillars of society, making alumni culture in the community more and more influential. The cultural standards of colleges and universities in terms of knowledge and morals are higher than that of the society and are the high-level performance of the culture in society. Alumni culture has its origins in the campus but extends its influence beyond the school [5]. When graduates with high-quality and high-cultural accomplishments leave the alma mater and enter the society, the alumni become a brand of their alma mater. He participates in various activities in the community to be active and healthy Behavior to show themselves, making the school's relevant information to be passed on to the outside world, making the school's spirit and style of school ethos to be displayed to the outside world, will inevitably play a role in the community radiation to promote social and cultural development [6].

\section{Conclusions}

Alumni culture is a more vivid educational resource and a more vivid way of education. Colleges and universities should raise their awareness, incorporate alumni culture into college students' ideological and political education, look for a meeting point and make full use of the influence of alumni culture on college students. Its ideological and political education with college students works effectively together.

\section{References}

[1] Liang Yong, An Xiumei, Ning Xiaohua. Alumni Association based on the function of cultural heritage analysis [J]. Societies Management Research. 2012 (06).12-15.

[2] Ding Qing.Study on the Role of University Alumni Culture in Campus Culture Construction [J]. Value Engineering. 2011 (30).456-458.

[3] Wang Jianxia. Cultivating alumni culture and trying hard to mold the inner spiritual character of campus culture [J] Journal of Central South University of Forestry and Technology (Social Science Edition), 2011 (05).123-125.

[4] QI Yin. Discussion on Alumni Cultural Construction in Higher Vocational Colleges [J]. Journal of Hubei Radio \& TV University. 2009 (03).114.

[5] Li Guoqiang. Perception of alumni culture [J]. Education Academic Monthly. 2008 (05).58-59

[6] Lei Jiabin, Zhang Jianguo, Hou Zhijun. Concept change and donation culture cultivation: alumni donation premise [J]. Modern Education Science. 2007 (01).78-79. 